\title{
NEGATÍV KAPCSOLATOK A SZERVEZETI HÁLÓZATOKBAN - MEGHATÁROZÁSOK, MÓDSZEREK ÉS MÉRCÉK
}

\section{NEGATIVE RELATIONSHIPS IN ORGANIZATIONAL SOCIAL NETWORKS - MODELS, METHODS AND MEASURES}

\begin{abstract}
Az elmúlt években a szervezetkutatásban és a tanácsadói gyakorlatban is növekvő figyelem irányult a szervezeti kapcsolathálózatok feltárására és elemzésére. E vizsgálatok azonban szinte minden esetben a pozitív kapcsolatokra összpontosítottak, miközben nem vették figyelembe, milyen hatást fejtenek ki a negatív kapcsolatok a hálózatokban. A negatív kapcsolatok (mint a bizalmatlanság, irigység vagy elkerülés) nem azonosak a pozitív kapcsolatok hiányával, és módszertani szempontból nem tekinthetők azok ellentéteinek sem. A negatív kapcsolatokat legegyszerűbben kognitív ítéletek, negatív érzések és más személyre irányuló magatartási szándékok relatíve tartós vagy visszatérően jelentkező eredőiként határozhatjuk meg. A tanulmány célja, hogy bemutassa a negatív kapcsolatok meghatározásait és modelljeit, illetve ismertesse a korábbi kutatások eredményeit (1) az egyének, (2) a diádok, (3) a triádok és (4) a teljes hálózat elemzési szintjein. A tanulmány felhívja a figyelmet az adatfelvétel és adatelemzés kihívásaira a negatív kapcsolatok kutatása során, amelyekre megoldásokat is kínál. A szakirodalmi áttekintés elsősorban a témában 2010 óta megjelent nemzetközi szakcikkek eredményeit összegzi.
\end{abstract}

Kulcsszavak: szervezeti hálózatkutatás, kapcsolathálózatok, személyközi kapcsolatok, negatív kapcsolatok, pletyka, irigység, elkerülés

Over the past few years, exploration and analysis of organizational social networks have been attracting increasing attention in both organizational research and consulting practice. These inquiries, however, focused almost exclusively on positive social relationships, while they ignored the effects of negative relationships in these networks. Negative relationships (e.g. distrust, envy, or avoidance) are not equivalent to the absence of positive relationships, neither are their opposites. Negative relationships are generally defined as relatively enduring relationships including negative cognitions (judgements), negative affections (feelings) and behavioral intentions towards others. This paper aims to introduce the definitions and models of negative relationships, as well as to present previous research findings at (1) individual, (2) dyadic, (3) triadic, and (4) whole network levels of analysis. It articulates challenges posed by data collection and data analysis techniques during network research on negative relationships and offers possible solutions. The literature review is primarily based on research articles and concept articles published after 2010.

Keywords: organizational network analysis, organizational social networks, negative ties, negative relationships, gossip, envy, avoidance

Finanszírozás/Funding:

A tanulmány az Emberi Erőforrások Minisztériuma ÚNKP-2017-3 kódszámú Új Nemzeti Kiválóság Programjának támogatásával készült.

\section{Szerző/Author:}

Baksa Máté, PhD-hallgató, Budapesti Corvinus Egyetem (mate.baksa@uni-corvinus.hu)

A cikk beérkezett: 2018. 11. 12-én, javítva: 2019. 03. 04-én, elfogadva: 2019. 03. 12-én.

This article was received: 12.11.2018, corrected: 03.04.2019, accepted: 12.03.2019. 
E gyre több kutató értelmezi a szervezeteket személyközi kapcsolatok hálózataiként (Kiss, 2005; Kürtösi, 2007; Török, 2005), amelyekben az eredményes müködésükhöz szükséges információ és tudás áramlik (Baksa \& Drótos, 2018; Hortoványi \& Szabó, 2006), illetve amelyekben bizalmon alapuló együttmüködések jönnek létre (Van Wijk et al., 2008). A szervezeti hálózatkutatás elsősorban az egyének, illetve a csoportok közötti kapcsolatok vizsgálatára koncentrál - annak érdekében, hogy feltárja a szervezeti müködés olyan aspektusait, amelyek sok esetben a szervezeti tagok és vezetöik szeme elött is rejtve maradnak (Cross \& Parker, 2004). A hálózatos megközelítést alkalmazó korábbi kutatások témái meglehetősen szerteágazók, jelentőségük és módszertani egységességük miatt azonban egyre inkább önálló paradigmaként tekinthetünk ezekre. Általában igaz rájuk, hogy a hálózati szereplők közötti kapcsolatokat pozitívnak tekintik (Snow \& Fjeldstad, 2015).

A szervezeti hálózatkutatás egyik fontos, mégis kevesebb figyelemre számot tartó területe a szervezetekben kialakuló negatív kapcsolatok vizsgálatával foglalkozik. A negatív kapcsolatok olyan személyközi viszonyokat jelölnek egy kapcsolathálózatban, amelyekben legalább az egyik fél viszonylag tartósan negatív érzelmekkel vagy magatartási szándékokkal viseltetik a másik iránt (Labianca, 2014). A téma kutatói elsősorban azzal érvelnek a terület fontossága mellett, hogy a negatív kapcsolatok az általában kizárólag pozitív (pl. bizalom, tisztelet) vagy semleges (pl. együttmüködés, segítségnyújtás, tudásátadás) kapcsolatokat elemző kutatások és tanácsadói diagnózisok vakfoltjában maradnak (Labianca \& Brass, 2006). Hiszen, ha a feltett kérdések csak pozitív kapcsolatok meglétét vizsgálják, az ezek alapján kirajzolódó hálózati térképről nem láthatjuk, hogy a helyenként hiányzó kapcsolatok nem fednek-e meglévő konfliktusokat és problémákat. Könnyen belátható, hogy nem kaphatunk teljes képet anélkül, hogy vizsgálnánk az azonosított véleményvezérek elutasítottságát, az innovációs hálózatokban megjelenő irigység visszatartó erejét, vagy az együttműködéseket gátló konfliktusokat hogy csak néhány példát említsünk.

Tanulmányom célja, hogy a vonatkozó nemzetközi szakirodalom áttekintésével bemutassam a negatív kapcsolatok legfontosabb meghatározásait, összefüggéseit, és a témát elhelyezzem a hazai tudományos vizsgálódás fókuszterületei között, ezzel segítve későbbi kutatások előkészítését. A téma hazai megjelenítése hozzájárulhat a hálózatos megközelítést alkalmazó szervezetkutatások fejlesztéséhez, illetve a tanácsadói praxisban pontosabbá teheti a kapcsolathálózatokat elemző diagnosztikai eszközöket.

A tanulmányom alapjául szolgáló irodalomkutatás áttekintő-feltérképező (exploratory) jellegü (Adams et al., 2007). Ennek oka, hogy a téma a nemzetközi szakirodalomban is viszonylag újszerü, ezért még nem született olyan nagyszámú publikáció, amelynek áttekintése szisztematikus irodalomfeldolgozást tenne lehetővé. A szakirodalom felkutatása és feldolgozása során kevert módszertant (Grant \& Booth, 2009) alkalmaztam: első körben kulcsszavas keresést, második körben pedig a hivatkozási jegyzékekre támaszkodó célzatos keresést, illetve hólabdamódszert használtam. A kulcsszavas keresés során olyan, az EBSCO és Science Direct adatbázisokban található referált folyóiratcikkekre szürtem, amelyek 2010 után jelentek meg, és amelyek címében vagy absztraktjában hálózati kontextusban szerepelt a „negative tie” vagy a „negative relationship" kifejezés. Az így kapott találatok közül kizártam a más tudományterületen megjelent tanulmányokat, majd további szakmai és tartalmi szempontok alapján szelektáltam: olyan cikkeket kerestem, amelyek több eltérő elemzési szintet (egyén, diád, triád, teljes hálózat) és több kapcsolattípust is érintenek. Mivel látható volt, hogy a téma egyik leginkább meghatározó szerzője Giuseppe Labianca, a University of Kentucky LINKS Center for Social Network Analysis professzora, az ő és szerzőtársai munkásságát külön is áttekintettem.

\section{A negatív kapcsolatok meghatározásai}

A szervezeti szociológiai és szociálpszichológiai alapokon nyugvó szervezeti hálózatkutatás közel egyévszázados hagyományokkal rendelkezik: a morenói szociometriától (Mérei, 2006) napjaink kifinomult tanácsadói diagnosztikai eszközeiig számos fontos elméleti is gyakorlati eredmény született. E vizsgálatok során általában a munkatársak közötti bizalmi kapcsolatokra, a munkához kapcsolódó információáramlásra és segítségnyújtásra, illetve az együttmüködésre, közös tanulásra és problémamegoldásra kérdeznek rá a kutatók (Cross \& Parker, 2004; Cross \& Thomas, 2009). Kutatásuk célja, hogy a különböző hálózati mintázatok feltárásával addig ismeretlen információkkal szolgáljanak a szervezet és annak vezetői számára. De mi a helyzet a negatív kapcsolatokkal? Ezek talán a pozitív kapcsolatok hiányának felelnek meg? Vagy talán a pozitív kapcsolatok ellentétei? Az eddigi kutatások alapján mindkét kérdésre nemmel felelhetünk.

A negatív kapcsolatok pontos meghatározása előtt érdemes röviden áttekintenünk a szervezeti hálózatkutatás történeti előzményeit. A pozitív kapcsolatok mellett konfliktusokat és más negatív viszonyokat is elemző vizsgálatokat már a korai szociológiai és szervezeti hálózatkutatók is készítettek (Labianca, 2014). Ez a megközelítés azonban Granovetter gyenge kapcsolatok erejéröl szóló úttörő cikke (Granovetter, 1973) nyomán háttérbe szorult, és csak az 1990-es évek végén került ismét a tudományos közösség figyelmének fókuszába (lásd Brass \& Labianca, 1999; Labianca, Brass, \& Gray, 1998). A negatív kapcsolatok szisztematikus kutatásának alapját Bourdieu (1986) és Coleman (1988) munkái fektették le. E kutatások a kapcsolati tőke fogalmát vizsgálták: érdekes kérdéssé vált, milyen kapcsolattípusok növelik, s melyek csökkentik a hálózati szereplők kapcsolati tőkéjét. A szervezeti hálózatkutatás tudományos és tanácsadói alkalmazása egyre elterjedtebbé vált a 2000-es évek második felében, majd különösképpen a 2010-es években. E növekvő népszerüségnek köszönhetően és a kapcsolatitőke-kutatások nyomán született több fontos megállapítás a negatív kapcsolatok összefüggéseiről. 


\section{A negatív kapcsolatok nem azonosak a pozitív kapcsolatok hiányával}

A pozitív kapcsolatok hiányát Burt (2005) strukturális réseknek nevezi, s felhívja a figyelmet ezek hálózati jelentőségére. A strukturális rések a kapcsolati hálózat egyes körülhatárolható részei (fürtök) közötti kapcsolatok hiányaként jelennek meg, vagyis olyan ,üres területek" a társas térben, amelyek nem redundáns információforrásokat választanak el egymástól. Burt rávilágít arra, hogy a strukturális réseket felszámoló közvetítők (broker) számottevő kapcsolatitőke-többletre tehetnek szert tevékenységükkel (Burt, 2005). Ez a szabályszerüség - egyéni hasznot maximalizáló szereplőket feltételezve - a közvetítők számára racionális magatartássá teszi a strukturális rések fenntartását és reprodukcióját. Ha egy pozitív kapcsolatokat megjelenítő tetszőleges hálózatot vizsgálunk, láthatjuk a strukturális réseket, azonban nem tudhatjuk, ezek mögött milyen esetekben találhatunk meglévő negatív kapcsolatot is. A későbbiekben olyan kutatási eredményeket is bemutatok, amelyek azt jelzik, hogy a strukturális résekhez hasonlóan a negatív kapcsolatok is növelhetik egy hálózati szereplő (ego) kapcsolati tőkéjét - azonban csak más szereplők (alterek) kárára.

A kapcsolatitőke-kutatások egy része nem az adott hálózati szereplö kapcsolatainak tartalmát, hanem ezek szerkezetét vizsgálja, különös tekintettel kapcsolati hálójának kiterjedtségére. Shipilov és szerzőtársai az ego-háló kiterjedtségét három tényező segítségével írják le: (1) a személyes hálózat sürüségével, vagyis ego ismerősei öszszekapcsoltságának mértékével, (2) a hálózat méretével, vagyis a kapcsolatok számosságával és (3) a kapcsolatok diverzitásával, illetve heterogenitásával (Shipilov et al., 2014). Longitudinális vizsgálatok során sikerült kimutatni, hogyan hatnak bizonyos környezeti tényezők (pl. pozitív vagy negatív vezetői értékelések) a munkatársak saját kapcsolati tőkéjükkel kapcsolatos viselkedésére (Parker et al., 2016). Eredményeik alapján azt állapították meg, hogy a negatív tényezők csökkentik, míg a pozitív tényezők növelik az új kapcsolatok kialakításának gyakoriságát. Ezen keresztül tehát a negatív hatások csökkentik, a pozitív hatások pedig növelik a vizsgálati alany kapcsolati tőkéjét.

A klasszikus kapcsolatitőke-kutatások, bár jelentős eredményeket értek el, nem vették figyelembe a negatív kapcsolatok által kifejtett hatásokat a szervezeti hálózatokban. Először Brass és Labianca (Brass \& Labianca, 1999; Labianca \& Brass, 2006) vetették fel, hogy a kapcsolati tőkét rögzítő, virtuális „,kapcsolati fökönyv” (social ledger) nemcsak tartozik, de követel oldallal is rendelkezik. Vagyis úgy vélték, a pozitív kapcsolatok növelik ego kapcsolati tőkéjét, míg a negatívak csökkentik azt.

\section{A negatív kapcsolatok nem a pozitív kapcsolatok ellentétei}

Ahogyan a negatív kapcsolatok nem tekinthetök a pozitív kapcsolatok hiányának, úgy nem tekinthetők egyszerüen azok ellentéteinek sem. Iskolai osztályokban végzett kutatások (Boda \& Néray, 2015; Csaba \& Pál, 2010; Telegdy, 2013) arra a következtetésre jutottak, hogy a negatív kapcsolatok hálózata nem a pozitív kapcsolatok hálózatá- nak inverze. Bár a pozitív hálózat központi szereplői nagyobb eséllyel szerepelnek a negatív hálózat perifériáján és kisebb eséllyel annak centrumában, ez fordítva nem feltétlenül igaz: könnyen lehet, hogy aki a negatív hálózatban periférikus szerepet tölt be, az a pozitív hálózatban is háttérbe szorul (Telegdy, 2013).

A korábbi kutatások úgy találták, hogy a negatív kapcsolatok a pozitív kapcsolatoktól sok tekintetben jelentősen eltérő dinamikával rendelkeznek (Labianca, 2014). Az egyik legalapvetőbb hálózati szabályszerüség, hogy az irányított (aszimmetrikus) kapcsolatok szimmetriára törekednek, vagyis előbb-utóbb várható, hogy reciprocitás, azaz kölcsönösség alakul ki bennük. A negatív kapcsolatok esetében azonban - részben a jóval nagyobb mértékü látenciának köszönhetően - ez az állítás ritkábban fogadható el (Szell \& Thurner, 2010). Különösen így van ez szervezeti környezetben, ahol a szervezeti kultúra magatartásnormái gyakran kifejezetten tabusítják az ellentétek nyílt felvállalását, így azok vagy más formában öltenek testet, vagy látensek maradnak. A látens ellentétek irányított negatív kapcsolatként jelenhetnek meg: ha egy hálózati szereplő (ego) negatívan viszonyul egy másikhoz (alter) de utóbbi nem szerez erről tudomást, a negatív kapcsolat nem lesz transzparens, és feltehetően viszonzott sem.

Úgy tünik, a negatív kapcsolatokra nem igaz a pozitív kapcsolathálózatokban megfigyelt tranzitivitási tétel sem: noha a barátom barátja gyakran az én barátom is, ugyanez nem mondható el az ellenségeim barátairól vagy a barátaim ellenségeiröl (Marineau et al., 2016). Ehelyett a negatív kapcsolatok mentén új szerepek definiálódnak: bizonyos hálózati szereplök ellenséges szereplök támogatásával vagy összebékítésével, esetleg negatív kapcsolatok létrehozásával tesznek szert hatalmi többletre. Összességében tehát azt láthatjuk, hogy a negatív kapcsolatok lényeges pontokon más szabályszerüségek szerint müködnek, mint a pozitív kapcsolatok (Labianca, 2014). Ezért szükséges külön meghatároznunk ezeket, és további vizsgálatokat folytatnunk annak érdekében, hogy dinamikájukat alaposabban feltárjuk.

\section{A negatív kapcsolatok mint személyközi attitüdök}

Labianca és Brass (2006) háromelemű meghatározása szerint a negatív kapcsolatok olyan relative tartós vagy visszatéröen jelentkezö diadikus jelenségek, amelyek más személyekre irányuló (1) kognitív ítéletek, (2) negatív érzések és (3) magatartási szándékok összességei. Meghatározásukban tehát a negatív kapcsolatokat alapvetően hosszabb időn keresztül fennálló negatív interperszonális attitüdöknek tekintik (vö. Bakacsi, 2004). E tripartit definíciót Labianca (2014) az affektív komponens (2a) valencia és (2b) arousal oldalaival egészítette ki: míg előbbi az érzelem irányultságára vonatkozik (pozitív-negatív), addig utóbbi az érzelem intenzitását fejezi ki (nyugodt-izgatott). E kiegészítés jelentőségét az adja, hogy a negatív kapcsolatok ilyen módon egyszerübben integrálhatók más kapcsolattípusok meghatározásával, illetve könnyebben összehasonlíthatók ezekkel. A valencia tengelyen megkereshetjük a pozitív kapcsolatok párjait (pl. bizalom-bizalmatlanság, együttmüködés-elkerülés, tisztelet-irigység), 
az arousal tengelyen pedig a gyenge és erős kapcsolatok közötti különbségeket jeleníthetjük meg (1. ábra)

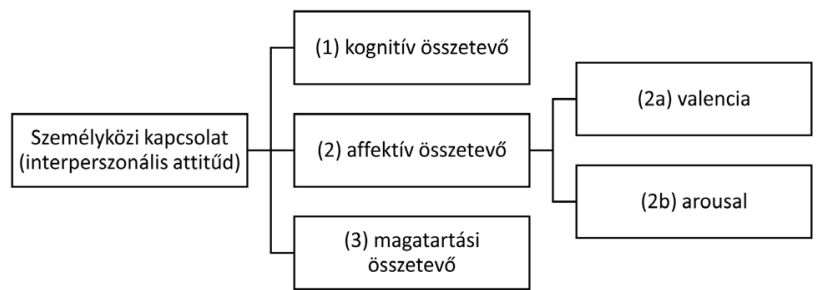

1. ábra A személyközi kapcsolatok hármas definíciója. Labianca (2014, p.244) alapján

Labianca (2014) felveti, hogy bár a fenti meghatározás önmagában teljes, és ezért elméletalkotási szempontból jól használható, a gyakorlati kutatások során nem szükséges mindhárom komponensre rákérdezni. A nemzetközi szakirodalomban láthatjuk, hogy ennek megfelelően a legtöbb tanulmány is általában egy-egy konkrét kapcsolattípus vizsgálatának eredményeit mutatja be. Ilyen például az elkerülés mint magatartási összetevő (Harrigan \& Yap, 2017), a bizalmatlanság mint kognitív összetevő (Marineau, 2017), vagy az ellenszenv mint affektív összetevő (Fujimoto et al., 2017). Könnyen találhatunk ugyanakkor olyan komplex kapcsolatokat is, amelyek feltárásához és megértéséhez több komponens egyidejű vizsgálata szükséges. (Mindazonáltal belátható, hogy a hálózatkutatás során gyakran alkalmazott kérdöíves adatfelvétel során egyegy kérdés segítségével egyszerre csak egy komponens vizsgálható.) Ilyen összetett kapcsolatnak tekinthető például az irigység, amely egy teljesítmény-összehasonlítás során észlelt (kognitív), másoknál rosszabb eredményre adott versengő vagy destruktív érzelmi válasz (affektív), illetve az ebből következő cselekvési (magatartási) szándékok összessége (Sterling \& Labianca, 2015).

\section{A negatív kapcsolatok mint interakciók és áramlások}

A szervezeti hálózatkutatás szakirodalmában egyaránt találkozhatunk a "tie” (él) és „node” (csúcspont), illetve a „relationship”(kapcsolat)és,,actor”(szereplő)kifejezésekkel (Robins, 2015). A gyakorlati hálózatkutatásban ezt a két fogalmat sokszor csereszabatosan használják, ugyanakkor fontos látni, hogy az elöbbi olyan matematikai-gráfelméleti kifejezés, ami egy hálózatban nemcsak szüken értelmezett kapcsolatot (társas viszonyt), de interakciót vagy áramlást is szimbolizálhat (Borgatti et al., 2014; Borgatti \& Halgin, 2011). Ha a negatív kapcsolatokat (,negative ties") interakciókként és áramlásokként értelmezzük, az a jelenségek szélesebb körét teszi kutathatóvá, ugyanakkor ezzel szükségszerüen eltérünk az előzőekben bemutatott attitüdszerű definíciótól, különösen annak relative tartós elemétől.

Borgatti és szerzőtársai (2014) aszerint tipizálták a diadikus jelenségeket (vagyis az ego és alter között felírható éleket), hogy azok valamilyen állapotot vagy eseményt jelenítenek-e meg. Előbbiek közé tartoznak a hasonlóságok, vagyis azok az attribútumok (pl. közös lokáció, közös csoporttagság vagy identitás), amelyek két személy között kapcsolatot teremthetnek; valamint a szüken értelmezett kapcsolatok (pl. szerepből adódó, affektív, ismeretségi), amelyek a korábban ismertetett tripartit definícióval leírhatók. Ezektől eltérő jelenségként tekinthetünk az interakciókra, vagyis a két személy közötti diszkrecionális eseményekre, amelyek tartós kapcsolatban, de azon kívül is megvalósulhatnak, illetve az áramlásokra, amelyek például a kapcsolatokban és interakciókban továbbított információkat, erőforrásokat, érzelmeket jelenítik meg. A negatív kapcsolatok mint diadikus jelenségek ilyen kiterjesztési lehetőségeit mutatja be a 2. ábra.

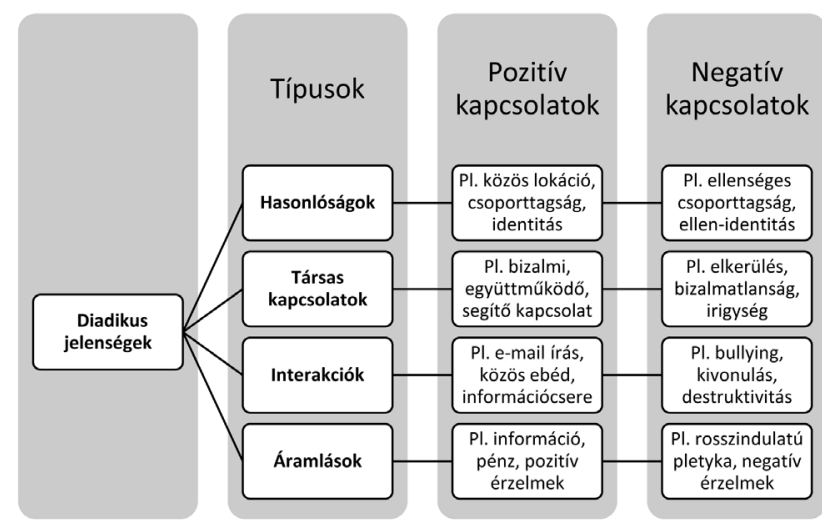

2. ábra A diadikus jelenségek kiterjesztett modellje. Borgatti és Halgin (2011) és Labianca (2014) alapján saját szerkesztés

A modell értelmezésekor további magyarázatot igényel az, hogyan függenek össze az interakciók és a kapcsolatok, illetve az interakciók és az áramlások: megjelenhetnek-e ezek a hálózatokban egymás nélkül. Mivel a társas kapcsolatok relatíve tartós személyközi jelenségek, ezeket akkor is létezőnek tekinthetjük, ha rövidebb-hosszabb ideig nem történik bennük interakció. Például elképzelhető, hogy egy külföldön dolgozó barátunkkal pár éve nem beszéltünk (vagyis nem léptünk vele interakcióba), mégis kölcsönösen barátnak tartjuk a másikat. A fizikai tér hálózataiban ritkán fordulhat elö, hogy áramlások interakciók nélkül jelennek meg. A vállalati praxisban is mind fontosabb közösségimédia-hálózatokban viszont láthatunk erre példát. A különböző online hálók „hírfolyam” felületein olyan áramlások mozognak, amelyekhez nem feltétlenül tartozik interakció: anélkül kaphatunk képi vagy szöveges információt ismerőseinkröl, hogy ezekről velük vagy másokkal beszélnénk (Kane et al., 2014).

A negatív kapcsolatok 2. ábrán látható meghatározása lehetővé teszi, hogy integráljuk és elméletileg is alátámasszuk a téma két fontos kutatási irányát. Ezek egyike a nagy hagyományokkal rendelkező pletykakutatás, amely itthon (Galántai et al., 2018; Szvetelszky, 2017) és külföldön is (Ellwardt et al., 2012; Grosser et al., 2010) fontos eredményeket ért el. Ezek szerint a pletyka - még ha rosszindulatú is - fontos szerepet tölt be a csoportok müködésében: egyrészt a normaszegők megbüntetésének, és ezen keresztül a csoportmüködés védelmének eszköze; másrészt segíthet a csoportidentitás megerősítésében is. A fenti eredményeket megalapozó kutatások (Ellwardt et al., 2012) arra jutottak, hogy a csoportban magas státusszal rendelkező személyek ritkábban lesznek negatív pletyka 
célpontjai, és hogy a pletykakapcsolatok eloszlása igen egyenetlen: gyakran néhány „bünbak” lesz a csoportban megjelenő pletykák céltáblája. A diadikus jelenségeket tipizáló modellben a pletykát az áramlások között helyezhetjük el, hiszen olyan információs tartalmakat értünk alatta, amelyeket más interakciók során, illetve kapcsolatok keretében adnak át a hálózati szereplők.

Egy másik fontos kutatási irány a közösségekben megjelenő bullying jelenségével foglalkozik. A bullying, vagyis a közösségen belüli megfélemlítés, lelki vagy testi kegyetlenkedés interakció típusú diadikus jelenség, hiszen ebben két hálózati szereplő (a bántalmazó és a bántalmazott) érintett, ugyanakkor közöttük többnyire nem alakul ki kinyilvánított vagy tartós kapcsolat. Noha az adatok hozzáférhetősége miatt a legtöbb vonatkozó kutatást iskolai osztályközösségekben végzik, ez a társas dinamika a munkaszervezetek világában is megfigyelhető. Holland általános iskolás osztályokban végzett vizsgálatok szerint az összes kapcsolat 3,4\%-a volt bullying kapcsolat a bántalmazók, és 5,1\%-a a bántalmazottak szerint (a népszerüségre és barátságra vonatkozó pozitív kapcsolatokhoz viszonyítva) (Tolsma et al., 2013). Bár a negatív kapcsolatok általában is nehezen mérhetők, látható, hogy ebben az esetben - irányított kapcsolatokról lévén szó - számottevő különbség tapasztalható ezek észlelésében. A bullying kapcsolathálózatokban betöltött jelentőségét akkor érthetjük meg, ha figyelembe vesszük a csoportok közötti konfliktusokban betöltött szerepét, illetve a státuszra gyakorolt hatását (Huitsing et al., 2012): a magasabb státuszú szereplőket ugyanis ritkábban bántalmazzák, ugyanakkor a bántalmazás magasabb státuszt eredményezhet.

\section{A negatív kapcsolatok meghatározásának nehézségei}

Az eddigiekben bemutatott definíciókat és modelleket tekintve láthatjuk, hogy a negatív kapcsolatok meghatározása nem egyszerü feladat. Ennek oka, hogy értelmezésükhöz bővítenünk kell a szervezeti hálózatkutatáshoz használt, némiképp leegyszerüsítő modelleket: távolabb kerülünk a gráfok matematikailag könnyen értelmezhető világától, ugyanakkor nem érjük el a pszichológiai értelmezések mélységi komplexitását. Noha a szervezeti hálózatkutatás episztemológiai és ontológiai alapvetéseinek ismertetése vagy kritikája kívül esik tanulmányom fókuszán, a továbbiakban mégis rövid kitérőt teszek, hogy bemutassam a negatív kapcsolatok kutatásának paradigmaformáló hatásait.

A hálózatkutatók az interperszonális kapcsolatokat uniformizáló módon kezelik: még ha meg is különböztetnek kapcsolattípusokat (pl. barátság), egy adott hálózatban nem tesznek különbséget az egy kapcsolattípusba tartozó egyedi kapcsolatok (pl. A és B vagy B és C szereplö barátsága) között, noha azok nyilvánvalóan több fontos jellemzőjükben eltérhetnek egymástól. Sok strukturalista kutató azonban ennél is tovább megy, és a kapcsolatok (élek) tartalmának jelentőségét eleve megkérdőjelezi (Borgatti et al., 2014). Számos tartalomalapú elméletnek, így Granovetter gyenge kapcsolatokról szóló megállapításának is megszületett a strukturalista kritikája: utóbbi szerint például elhanyagolható szempont a kapcsolat erőssége, valójában az összekapcsolt strukturális pozíciók különbözősége a meghatározó a kapcsolati tőke növekedése szempontjából (Borgatti \& Foster, 2003). Még ha a kutatók többsége az eredmények értelmezésekor tekintettel is van a kapcsolatok tartalmára és kontextusára, láthatjuk, hogy a szervezeti hálózatkutatás - az átfogóbb összefüggések és mintázatok feltárása érdekében - sok egyszerüsítéssel él, és modellszerủen gondolkodik az emberi kapcsolatokról.

A negatív kapcsolatok vizsgálata és meghatározása több szempontból is bonyodalmakat vet fel a szervezeti hálózatkutatás előfeltevéseiben. Egyrészt, a negatív kapcsolatok attitüdszerü definíciója - a strukturalista megközelítésekkel szemben - törekszik a kapcsolat komplex, többkomponensű leírására, ez pedig hasonló elvárásokat támaszthat a pozitív kapcsolatok meghatározásával kapcsolatban is. Másrészt, mivel a negatív kapcsolatok nem tekinthetők sem a pozitív kapcsolatok hiányának, sem azok ellentétének, a tartalmuk értelmezése nélkül (pusztán matematikai elemzésekkel) nem kezelhetők együtt a pozitív kapcsolatokkal. Értelemszerűen a pozitív kapcsolatok hálózatainál használt különböző centralitásmutatók is mást jelentenek, máshogyan értelmezhetők a negatív kapcsolatok esetében. Harmadrészt, a kapcsolathálózatok multiplex jellege miatt értelmezni kell azokat a helyzeteket, amikor két hálózati szereplő között egyidejüleg pozitív és negatív kapcsolat is fennáll.

A multiplex hálózatok egyes rétegei különböző kapcsolattípusokat jelenítenek meg a hálózati szereplők között (Borgatti \& Halgin, 2011). Például egy szervezeti egység munkatársai közötti különböző kapcsolatokat (barátság, tudásmegosztás, együttmüködés) különböző rétegekként ábrázolhatjuk. Pozitív kapcsolatok esetében az egyes rétegek gyakran hasonló hálózati mintázatokat rajzolnak ki, s ehhez köthető Coleman szerint (Borgatti et al., 2014) a kapcsolati tőke átválthatóságának (appropriability) fogalma: vagyis, ha lehetöségem van rá, szívesen választom a barátomat munkatársamnak, s szívesebben osztom meg vele meglévő tudásomat is. A valóságban az emberi kapcsolatok komplexitása miatt azonban gyakran előfordul, hogy két szereplö között pozitív és negatív kapcsolat is jelen van egyszerre: például ego és alter bizalmatlan egymással szemben, mégis együtt kell tanulniuk (Hortoványi \& Szabó, 2006), vagy egyikőjük szakmailag irigy a másikra, emberileg mégis felnéz rá.

A negatív kapcsolatok vizsgálatából adódó paradigmatikus kihívások miatt talán nem véletlen, hogy a téma prominens szerzői törekednek talán leginkább a szervezeti kutatásokban a hálózatos megközelítésmód és a pszichológiai eszköztár integrálására (Casciaro et al., 2015; Venkataramani et al., 2013). Úgy gondolom, hogy a negatív kapcsolatok meghatározásának nehézsége ellenére éppen ez lehet az, ami segít pontosítani, kiegészíteni, valóságközelibbé és mélyebbé tenni a szervezeti hálózatkutatás eredményeit.

\section{Korábbi kutatási eredmények és összefüggések}

Tanulmányom következő részében bemutatom a negatív kapcsolatok irodalmát bővítő kutatások néhány fonto- 
sabb eredményét. E megállapításokat és összefüggéseket a szervezeti hálózatkutatás elemzési szintjeinek megfelelően vezetem elő: elsőként az egyénhez, az egyes hálózati szereplőkhöz kapcsolódó eredményeket idézem, majd a diádok, a triádok és a teljes hálózati struktúra szintjeit érintő megfigyeléseket ismertetem. (Az elemzési szinteket és az érintett témákat a 3. ábra összegzi.) Tanulmányom terjedelmi korlátjai miatt nem célom, hogy az idézett kutatásokat azok teljességében bemutassam, ugyanakkor bízom benne, hogy ezek áttekintésével átfogó képet adhatok a téma iránt érdeklődő szakemberek számára, és ezzel további kutatásokat inspirálhatok.

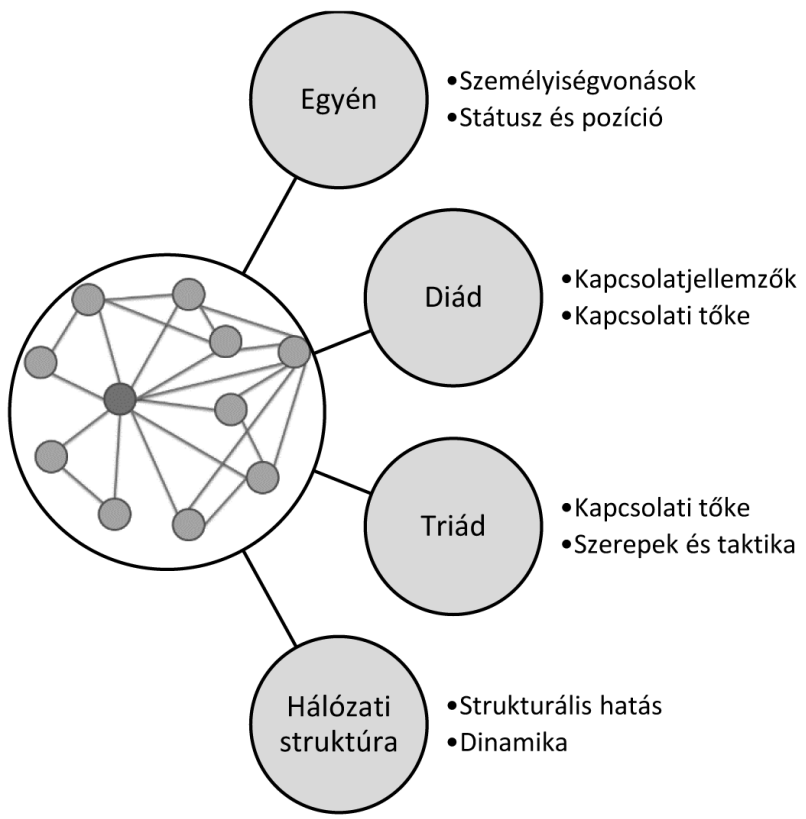

3. ábra A negatív kapcsolatok vizsgálatának fókuszterületei. Saját szerkesztés

\section{Negatív kapcsolatok a hálózati szereplők elemzési szintjén}

A hálózatkutatás elsősorban nem az egyénekkel, hanem a köztük létrejövő kapcsolatokkal és ezek mintázataival foglalkozik. Érdekes kérdés ugyanakkor, hogy a hálózati szereplök különböző attribútumai milyen módon befolyásolják e kapcsolatokat és a hálózatban betöltött szerepüket. E személyes attribútumok közül talán legfontosabbak (1) a személyiségvonások, illetve (2) a szervezetben betöltött státusz és pozíció.

Noha a személyiség kifejezés pontos tartalma és állandó mivolta, illetve az ezt leíró személyiségvonások száma és meghatározása napjainkban is vitatott, a személyiségpszichológia talán legfontosabb és legelfogadottabb elméleti konstrukciója a Big Five személyiségmodell (Carver \& Scheier, 2006). E szerint a személyiséget leíró öt faktorcsoport (a) az extraverzió, (b) a barátságosság, (c) a lelkiismeretesség, (d) az érzelmi stabilitás és (e) az élményekre való nyitottság. Labianca (2014) korábbi kutatásokra hivatkozva megállapítja, hogy minden olyan személyiségvonás, amely nagyobb személyes kapcsolathálózatot (ego-hálózatot) eredményez, egyszersmind több negatív kapcsolat létrejöttét is vonja maga után. Eszerint például a magasabb extraverzió értékkel rendelkező, szociálisabb személyek nagyobb kapcsolathálózattal, egyszersmind viszont több negatív kapcsolattal is rendelkeznek, mint introvertált társaik.

Más kutatások erős pozitív korrelációt találtak az alacsony érzelmi stabilitás, az alacsony barátságosság és a magas nyitottság értékek, illetve a negatív személyes kapcsolatok száma között (Klein, Lim, Saltz, \& Mayer, 2004 idézi Labianca, 2014). Bár a több kapcsolat (nagyobb személyes hálózat) mindig több negatív kapcsolattal is jár együtt, lényeges kérdés, hogy az adott személy kapcsolatai milyen arányban negatívak, vagyis milyen a kapcsolathálózat negativitása. E megkülönböztetéssel finomíthatjuk a személyiségvonások negatív kapcsolatok kialakulására gyakorolt hatásait. Mindennek szervezeti jelentősége abból adódik, hogy a kapcsolathálózat fokozódó negativitása végső soron alacsonyabb munkával kapcsolatos elégedettséget, alacsonyabb szervezeti elkötelezettséget és magasabb kilépési hajlandóságot eredményez (Venkataramani et al., 2013).

A hálózati szereplök státusza - amely egyaránt származhat formális hatalmi forrásokból és a kapcsolathálózatban betöltött pozícióból - többféle módon befolyásolja, hogy e szereplök mennyire kitettek a negatív kapcsolatoknak, hogyan észlelik ezeket, és hogyan reagálnak rájuk. Marineau és szerzőtársai kutatásukban azt vizsgálták, miképpen hat a formális és informális hatalom a hálózati struktúra észlelésének pontosságára (Marineau et al., 2018). Más kutatók korábban rámutattak (Kane et al., 2014), hogy az online társas tér kivételével a hálózati szereplők általában kevéssé sikeresek saját hálózati pozíciójuk felismerésében és a kapcsolathálózat egészének helyes észlelésében. Marineau és szerzőtársai ezzel szemben azt találták, hogy a magas státusz pozitívan befolyásolta az észlelés pontosságát: (1) a formális és informális hatalommal rendelkező személyek egyaránt pontosabban ítélik meg saját személyes kapcsolathálózatukat, akár pozitív, akár negatív kapcsolatokról van szó, (2) a formális hatalommal bíró szereplők a teljes hálózati struktúra átlátásában is sikeresebbek, (3) a formális hatalom birtokosai jelentősen eredményesebbek a negatív kapcsolatok észlelésében a teljes hálózati struktúrában (Marineau et al., 2018). Utóbbi összefüggést magyarázhatja az, hogy a vezetőknek jobban kell látniuk azokat a negatív kapcsolatokat, amelyek veszélyeztethetik a szervezeti célok teljesítését, de azt is, hogy a vezetőkhöz a negatív kapcsolatokról szóló hírek gyakrabban eszkalálódnak.

A státusz és a negatív kapcsolatok összefüggéseit a munkahelyi pletykakapcsolatokon keresztül vizsgáló kutatók (Ellwardt et al., 2012) azt állapították meg, hogy az alacsony státusz növeli annak valószínüségét, hogy valaki negatív pletyka céltáblája lesz, és ilyen módon bünbak szerepbe kerül. Iskolai osztályközösségeket vizsgáló kutatók (Huitsing et al., 2012) pedig arra hívták fel a figyelmet, hogy míg az egyformán magas státuszú, egyformán sok beérkező baráti kapcsolattal rendelkező szereplök között nagyobb valószínüséggel alakul ki barátság, ugyanez nem mondható el az egyformán sok negatív kapcsolatnak kitett szereplők esetében. Utóbbi állítás elsősorban azokban az esetekben igaz, amikor a negatív kapcsolatok más szerep- 
lők számára nem vagy kevéssé láthatók. Ellenkező esetben (pl. bullying áldozataként) nagyobb eséllyel keresnek társas támogatást ezek célpontjai.

\section{Negatív kapcsolatok a diádok elemzési szintjén}

A negatív kapcsolatok a korábban bemutatott meghatározásuk szerint alapvetően diadikus jelenségként értelmezhetők. Tanulmányom e pontján az elmondottakat (i) a kapcsolatokat leíró jellemzőik, illetve (ii) a negatív kapcsolatok és a kapcsolati tőke összefüggéseinek ismertetésével egészítem ki részletesebben. A negatív kapcsolatok leírásakor és elemzésekor mindenképpen tekintettel kell lennünk ezek (a) erősségére, (b) kölcsönösségére (reciprocitására), (c) felismertségére és (d) a társas térben értelmezett távolságára (Huitsing et al., 2012). A pozitív kapcsolatokhoz hasonlóan a negatív kapcsolatoknál is értelmezhetjük a kapcsolat erősségét, mégpedig elsősorban annak érzelmi intenzitása (erőteljes negatív valenciája és arousal értéke), illetve magatartásbefolyásoló hatása alapján. A konfliktusokat mint negatív kapcsolatokat vizsgálva például láthatjuk, hogy a feladattal kapcsolatos konfliktusok érzelmi intenzitása alacsonyabb a személyes konfliktusokénál, s általában ugyanerre az eredményre juthatunk az érdek- és értékkonfliktusok összehasonlításakor (Labianca, 2014).

A pozitív kapcsolatokhoz hasonlóan a negatív kapcsolatok esetében is igaz, hogy bizonyos kapcsolattípusok (pl. bullying) jellegükből adódóan irányítottak, ugyanakkor itt gyakran jelentősebb a látencia. Mivel a szervezeti kontextus bizonyos elemei - mint a kultúra vagy a formális hierarchiában elfoglalt helyzet - gyakran nem teszik lehetővé a negatív érzelmek és értékítéletek explicit kifejezését, a negatív kapcsolatok felismertsége általában alacsonyabb (Harrigan \& Yap, 2017). Ezzel összefüggésben e kapcsolatok gyakran viszonzatlanok, legalábbis addig, amíg rejtve maradnak. A negatív kapcsolatok lappangó jellege, valamint a tény, hogy a szervezetek gyakran tabusítják és szimbolikus terekbe kényszerítik ezeket, megnehezítik a téma kutatását. A negatív kapcsolatok társas térben értelmezett távolsága azt fejezi ki, hogy egy adott hálózati szereplőt közvetlen (direkt) szálak füznek más szereplőhöz vagy egy másik kapcsolatukon keresztül indirekt módon kapcsolódnak össze: nem lényegtelen, hogy saját ellenlábasunkról vagy egy barátunk ellenlábasáról van-e szó.

Labianca és Brass (2006) a negatív kapcsolatokra úgy hivatkozik mint ego kapcsolati tőkéjét (vagyis a céljai elérése érdekében, kapcsolatain keresztül mozgósítható erőforrásait) csökkentő tényezőkre. Meglátásuk szerint ugyanis azok a személyek, akiket egohoz negatív kapcsolatok füznek, nem csupán értékes erőforrásokat (szervezeti kontextusban például információt, befolyást vagy pénzügyi eszközöket) tarthatnak vissza tőle, de tevőlegesen is akadályozhatják céljai elérésében (lásd a korábban ismertetett definíció magatartási összetevőjét). Ebből adódóan úgy vélik, hogy az elöbbiekben bemutatott kapcsolati jellemzők közül a negatív kapcsolatok erössége, kölcsönössége és felismertsége növeli, míg a társas térben értelmezett távolság csökkenti ezek kapcsolati tőkét erodáló hatását (Labianca \& Brass, 2006). A kapcsolatháló- zatokat erőforrás-alapú megközelítésben vizsgáló kutatók ezt a hatást annyira fontosnak tartják, hogy azt ajánlják, összetett és esetenként nehézkes definíciók helyett a negatív kapcsolatokat egyszerüen határozzuk meg a kapcsolati tökét csökkentö kapcsolatokként (Borgatti et al., 2014). A triádákon végzett kutatások azt igazolják, hogy nem ilyen egyszerü a helyzet - és ez a meghatározás egyébként is túlságosan leegyszerüsítő.

\section{Negatív kapcsolatok a triádok elemzési szintjén}

A triádok a teljes hálózat legkisebb, kapcsolati szinten túlmutató részstruktúrái, amelyek - ahogyan nevük is utal rá - három hálózati szereplőt és közöttük megjelenő kapcsolatokat foglalnak magukban. A triadikus kutatások előnye, hogy egyetlen kapcsolat vizsgálata helyett annak közvetlen környezetével is foglalkoznak, így különösen alkalmasak szervezeti szituációk leírására. A negatív kapcsolatok esetében is izgalmas lehet az indirekt kapcsolatok vizsgálata, vagyis például annak feltérképezése, miképpen hat egy hálózati szereplőre a tőle két lépésre található konfliktus, ellenszenv vagy bizalmatlanság. Marineau és szerzőtársai (2016) nyílt és zárt triádokon végezték kutatásukat. Az általuk vizsgált négy fö típust a 4. ábra foglalja össze.

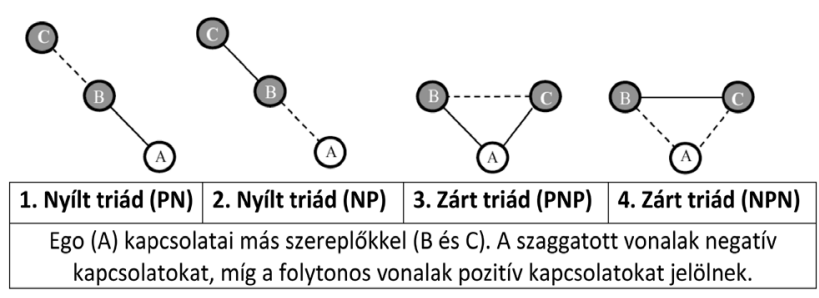

4. ábra Direkt és indirekt negatív kapcsolatok triádokban. Marineau et al. (2016, p.241) alapján

Nyílt triádokról akkor beszélünk, ha A, B és C hálózati szereplök között összesen két kapcsolat van, zárt triádokról pedig akkor, ha mindhárom potenciális kapcsolat létezik. Elöbbieken belül megkülönböztethetjük azokat az eseteket, amelyekben ego barátja áll valakivel negatív kapcsolatban (PN) és azokat, amelyekben ego olyasvalakivel áll szemben, akit egy barátja támogat (NP). A zárt triádok első típusában ego barátai közötti negatív kapcsolattal találja szembe magát (PNP), második típusában pedig ő maga száll szembe egy vele ellenséges szövetséggel (NPN).

Noha azt számos kutatás megerősítette, hogy a közvetlen (direkt) negatív kapcsolatok csökkentik a vizsgált hálózati szereplő kapcsolati tőkéjét és produktivitását, a közvetett (indirekt) negatív kapcsolatok ennél összetettebb helyzeteket eredményeznek. Marineau és szerzőtársai arra jutottak, hogy az indirekt negatív kapcsolatok még ha a közvetlenül érintett személy és a hálózat egésze számára negatív következményekkel járnak is - bizonyos szereplök számára hasznot is hajthatnak (Marineau et al., 2016):

a) PN nyílt triádok esetében az $A$ és $B$ jelü szereplők között függő helyzet jöhet létre, amelyben $A$ érzelmi és egyéb erőforrásokkal támogatja $B$ szereplőt 
a $C$-vel fennálló konfliktusában. Ez $A$-t a támogató bizalmas szerepébe helyezheti, aki ezáltal növelheti informális hatalmát és $B$-vel szembeni erkölcsi tőkéjét, végső soron saját teljesítményét.

b) NP nyílt triádok esetében $A$ szereplőt nem sújtja jobban a $B$-vel szemben fennálló konfliktusa amiatt, hogy $B$ szereplöt $C$ támogatja ebben - vagyis egy negatív kapcsolat mellett megjelenő indirekt pozitív kapcsolat nem ront A szereplö pozícióin.

c) NPN zárt triádok esetében azonban $B$ és $C$ szereplők már képesek egyesíteni erőiket A szereplő ellenében, így A helyzete és teljesítménye számottevően romlik - a vizsgált szereplő ellenlábasai közötti szövetség (közvetett kapcsolat) tehát erőteljes hatást gyakorol a közvetlen negatív kapcsolatokra is.

d) PNP zárt triádok esetében $A$ szereplő már nem tudja „,büntetlenül” kihasználni a PN nyílt triádokban is fennálló támogató pozícióját, hiszen minden baráti gesztus $B$ vagy $C$ felé bizalmatlanságot szül vele szemben a másikban. Ez esetekben $A$ pozitív kapcsolata megszakad $B$ vagy $C$ szereplővel (sok esetben mindkettőjükkel) hosszabb távon, és már rövidebb távon is romlik a teljesítménye amiatt, hogy ebben az instabil helyzetben kell manővereznie.

Látható tehát, hogy a negatív kapcsolatok mentén kialakuló mintázatokból egy-egy hálózati szereplő profitálni is képes, elsősorban PN nyílt triádokban. A tertius gaudens-nek, vagyis nevető harmadiknak nevezett jelenség tehát nem csak a strukturális réseket (Burt, 2005) áthidaló személyek esetében, de a negatív kapcsolatok közelében is a kapcsolati tőke növekedését idézheti elő bizonyos szereplők számára. Szintén a strukturális rések elméletéhez tartozó fogalom a tertius iungens, vagyis az összekötő harmadik. Azon szereplöket nevezzük így, akik - a nevető harmadikhoz képest épp ellenkezőleg - azáltal tesznek szert nagyobb kapcsolati tőkére és informális hatalomra, hogy egyébként izolált szereplőket kapcsolnak össze, vagy fokozzák a közöttük lévő interakciók mértékét (Obstfeld, 2005). Érdekes azt látnunk a PNP zárt triádok példáján, hogy a tertius iungens taktika negatív kapcsolatok esetében nem tünik müködőképesnek, sőt, könnyen ellentétes eredményre vezethet.

$\mathrm{Az}$ eddigiekben bemutatott kutatások fontos korlátját jelenti, hogy kapcsolathálózati pillanatképeket elemeztek, és nem vizsgálták a negatív kapcsolatok dinamikus tulajdonságait. Úgy gondolom, hogy ilyen irányú kutatások komoly eredményekkel kecsegtetnek, amelyeket ezért érdemes a téma iránt érdeklődő kutatók figyelmébe ajánlanom: a negatív kapcsolatok longitudinális vizsgálata nem csupán az élképződés (kapcsolatalakulás) szabályszerüségeit világíthatná meg, de segíthetne feltárni a negatív kapcsolatok mentén megjelenő egyéni viselkedésmintázatokat és taktikákat is. Kik azok a szereplők, akik az Oszd meg és uralkodj! parancsának engedve rendre generálják maguk körül az indirekt negatív kapcsolatokat, hogy aztán nevető harmadikként ezekből profitáljanak? Kik azok, akik épp ellenkezőleg, békítőleg igyekeznek fellépni, hogy ilyen módon stabilizálják a hálózatukat? Kik azok, akik különböző okok miatt maguk keresik a konfliktusokat? Kik azok, akikkel újra és újra harcos szereplők „,fegyverhordozóiként" találkozhatunk? A hálózatelmélet oldaláról megfogalmazott válaszok egyelöre váratnak magukra, pedig a kérdések nem újkeletűek: a görög mitológia folyton viszálykodó istenségei között is megtaláljuk a nyílt konfliktusok (Arész), a rejtett cselszövés (Hadész), a viszályszítás (Erisz) és a békéltetés (Eiréné) megtestesítöit.

\section{Negatív kapcsolatok a teljes hálózati struktúra elemzési szintjén}

A negatív kapcsolatok vonatkozásában a teljes hálózati struktúra szintjén megfigyelt egyik legalapvetőbb jelenség a negatív aszimmetria, vagyis az a jellegzetesség, hogy a negatív kapcsolatok kisebb relatív gyakoriságuk ellenére is erőteljes hatást gyakorolnak a hálózat szerkezetére. A negatív kapcsolatok tényleges számát a jelentős mértékü látencia miatt nehéz pontosan megmérni, de arányukat a teljes kapcsolathálózatban általában 5-10\% közé tehetjük (Labianca, 2014; Labianca \& Brass, 2006). Mivel ritkábbak, a pozitív kapcsolatoknál sokkal több információt hordoznak a hálózat szerkezetéről, és általában hatásaik is szerteágazóbbak.

A negatív aszimmetria jelenségét Labianca és Brass (2006) pszichológiai tényezőkkel magyarázta. Taylor (1991) nyomán amellett érvelnek, hogy az emberi észlelés általában úgy alakult, hogy a negatív eseményeknek nagyobb figyelmet tulajdonítunk, s ez élénkebb pszichológiai müködést eredményez, magasabb arousal szinthez, illetve erőteljesebb kognitív, affektív és viselkedési aktivitáshoz vezet. Ezen állításukat részben az evolúciós pszichológia eredményeivel (a kockázatkerülők jobb túlélési esélyeivel), részben pedig a fejlődéspszichológia megfigyeléseivel (a tiltások, büntetések és negatív környezeti tényezők kifejtette nevelő hatással) támasztják alá. Az elöbbiekben bemutatott kutatások e hatást több téma kapcsán megerősítették (pl. hálózati észlelés, teljesítmény, státusz). A vállalati gyakorlat mindennapjaiból példát hozva könnyen beláthatjuk, hogy bár két stratégiailag fontos szervezeti egység vagy szereplő közötti pozitív kapcsolat sok hasznot hajthat, a közöttük fennálló negatív kapcsolat vagy konfliktus megbéníthatja, végső soron válságos helyzetbe sodorhatja a szervezet egészét.

A negatív kapcsolatok hálózati elemzési szintjével összefüggésben kell megemlítenünk e kapcsolatok eltérő müködési mechanizmusait is. A pozitív kapcsolatok esetében az élképződés, vagyis egy-egy új kapcsolat kialakulása alapvetően hat ok valamelyikére vezethető vissza (Harrigan \& Yap, 2017):

i. fürtösödés (closure): a nyílt triádok törekednek a zárttá válásra - vagyis egy hálózati szereplő nagyobb eséllyel alakít ki kapcsolatot olyasvalakivel, akivel van közös barátja,

ii. kölcsönösség (reciprocity): az irányított kapcsolatok törekednek a viszonosságra - vagyis egy hálózati szereplő nagyobb valószínüséggel barátkozik olyannak, aki vele barátságos,

iii. összeválogatódás (homophily): a valamilyen szem- 
pontból hasonló szereplők között nagyobb valószínüséggel alakul ki kapcsolat - „madarat tolláról, embert barátjáról",

iv. népszerüség (popularity): azok szereplők, akikhez sok irányított kapcsolat érkezik, nagyobb valószínüséggel tesznek szert újabb kapcsolatokra - a ,gazdag gazdagabbá válik" elv,

v. aktivitás (activity): azok a szereplők, akiktől sok irányított kapcsolat indul, nagyobb eséllyel kezdeményeznek további kapcsolatokat,

vi. kibővités (entrainment): azok között a szereplök között, akik között már van valamilyen típusú kapcsolat, könnyebben alakul ki más típusú kapcsolat is.

Úgy tünik, hogy míg a pozitív hálózatokban e hat mechanizmus mindegyike okozhatja egy-egy újabb kapcsolat létrejöttét, addig a negatív kapcsolatok esetében az első három mechanizmus hatása erősen korlátozott (Harrigan \& Yap, 2017). A fürtösödési tendencia hiánya jól levezethető a triádok korábban bemutatott dinamikájából, a kölcsönösség korlátozott megjelenése pedig a negatív kapcsolatok nagymértékü látenciájának köszönhető (a külső környezet vagy a konfliktus pszichológiai költségei miatt ezek gyakran irányítottak és rejtettek maradnak).

Harrigan és Yap (2017) kutatása arra az eredményre jutott, hogy a homofília helyett a negatív kapcsolatok esetében értelmezett heterofóbia, vagyis a különbözőség kapcsolatteremtő hatása, csak akkor jelentkezik, ha a vizsgált attribútum nagyon megosztó és érzelmileg telített. Eredményeiket azzal magyarázzák, hogy a negatív kapcsolatokban gyakran megjelenik az elkerülés magatartási komponens (akár fizikai elkerülés, akár titkolózás, tabusítás formájában), ami indokolja az első három mechanizmus előfordulásának hiányát. Csaba és Pál (2010) iskolai osztályokat vizsgálva hasonló eredményekre jutott: azt találták, hogy egyes attribútumok (pl. a nem vagy a „stréberség”) esetében nem jelentkezik a heterofóbia, míg más attribútumoknál (pl. a szépség) erőteljesen megjelenik. A kapcsolati dinamikában megfigyelt eltéréseket mások is megerősítették például a kapcsolati tranzitivitás oldaláról: úgy tünik, hogy az ellenségünk barátja nem feltétlenül lesz az ellenségünk, s az ellenségünk ellensége sem feltétlenül lesz barátunk (Csaba \& Pál, 2010; Szell et al., 2010; Szell \& Thurner, 2010).

\section{Módszerek és mércék az adatfelvételben és -elemzésben}

A negatív kapcsolatok lekérdezése általában még több körültekintést igényel, mint a pozitív kapcsolatoké, még inkább fontos, hogy megfontoljuk a kutatói és tanácsadói etika szempontjait. A nehézségek egy része az adatok felvételéhez kötődik: (a) a negatív kapcsolatokra vonatkozó adatok igen érzékenyek, (b) gyakran jelenik meg a titkolózás, hogy minél kisebb eséllyel kelljen megfizetni egy mindeddig látens konfliktus nyilvánossá válásának pszichológiai költségeit, (c) a külső környezet, például a szervezeti kultúra pedig sokszor tabusítja ezek megjelenését a nyilvános térben. A nehézségek másik része az adatok elemzéséhez kötődik: (d) a negatív kapcsolatok legtöbbször irányítottak, a pozitív kapcsolatoktól eltérő mechanizmusok müködtetik őket - az elemzés során gyakran mégis ezekkel együtt értelmezendők.

\section{Adatfelvételi módszerek}

A szervezeti hálózatkutatás rendkívül hatékony diagnosztikai eszközként használható bizonyos szervezeti szituációk feltérképezésére, ugyanakkor jellegéből adódóan több etikai kérdést vet fel más módszereknél (Cross et al., 2013). A hálózatos adatok felvétele nem történhet anonim módon, hiszen épp az összekapcsolódó munkatársak neveire vagyunk kíváncsiak; ráadásul más kitöltők válaszain keresztül olyan személyekröl is megtudhatunk érzékeny információkat, akik nem kívánnak részt venni a kutatásban. A kapcsolatok tartalma - különösen a negatív kapcsolatok esetében - kifejezetten szenzitív lehet, hiszen ezek sokszor átívelnek a szakmai és személyes szerepek határán. Mivel a vizsgálatból kimaradó stratégiai jelentőségű kapcsolatok téves értelmezésekhez vezethetnek, a hálózatkutatók számára elengedhetetlen, hogy a lehető legnagyobb arányban kapjanak válaszokat a vizsgált szervezet vagy csoport tagjaitól (Borgatti \& Molina, 2003). Az adatok nagyfokú érzékenysége és a begyüjtésük szükségessége bizonyos esetekben nehéz helyzetek elé állíthatja a kutatókat, akiknek ezért különös figyelmet kell fordítaniuk, hogy megtalálják az etikai szempontok szerint elfogadható megoldásokat. A negatív kapcsolatok vizsgálatakor is kifejezetten fontos, hogy tisztázzuk a válaszadók számára, az adatokhoz és a kutatási eredményekhez ki és milyen aggregáltsági szinten férhet hozzá, hiszen ez a válaszadási hajlandóságot is alapvetően befolyásolhatja (Robins, 2015).

Az etikai kérdések mellett a szervezeti kultúrában is gyökerező alkalmazhatósági szempontokat is érint az, hogy egy kérdöívben hogyan fogalmazzuk meg a negatív kapcsolatokra vonatkozó itemeket (Labianca, 2014): az „ellenség”, „utálat” és hasonló kifejezések túlságosan erősek, érzelmileg telítettek, használatuk így nemcsak a válaszadókat rettentheti el, de a vizsgálati szervezet vezetőinek rosszallását is maga után vonhatja. Ezek a megfogalmazások episztemológiai dilemmákat is támasztanak. A pozitív kapcsolatok esetében talán könnyebben érvelhetünk amellett, hogy egy nexusra vonatkozó kérdés feltételével a kutatók nem változtatják meg jelentősen a vizsgálat tárgyát, ám az általában magasabb arousal szintet előidéző negatív kapcsolatoknál komolyabb kockázatot jelent, hogy a „,nemszeretem” kollégák listázása maga is megerősíti ezeket a negatív ítéleteket és érzelmeket.

Bár bizonyos negatív kapcsolattípusok (pl. bullying) esetében jellemzően nem lehet eltekinteni attól, hogy ezekre direkt és explicit módon rákérdezzünk, a legtöbb esetben a megfogalmazás finomításával és a kérdések több részre bontásával érhetünk el jobb eredményeket. A név értelmezö (name interpreter) módszer lényege például, hogy első lépésben a kapcsolat meglétére kérdez rá, s csak ezt követően vizsgálja annak valenciáját (Robins, 2015). Vagyis elkerülő vagy munkakonfliktus kapcsolatoknál például először arra kérjük a válaszadókat, hogy sorolják 
fel azokat a kollégáikat, akikkel a munkájuk során rendszeresen kapcsolatba kerülnek. Ezt követően egy másik itemben azt a feladatot adjuk nekik, hogy egy Likert-skálán értékeljék, mennyire könnyű vagy nehéz együttmüködni a felsoroltakkal, esetleg mennyire szívesen vagy kevéssé szívesen töltenek időt velük. Ez a módszer még olyan összetett kapcsolattípusok esetében is müködhet, mint az irigység. Az irigységet értelmezhetjük a munkatársakkal való összehasonlításban észlelt alacsonyabb teljesítmény felett érzett fájdalomként és ebből fakadó destruktivitásként (Sterling \& Labianca, 2015; Tai et al., 2012). Ez alapján először vizsgálható annak kérdése, hogy az érintett szereplö kivel hasonlítja össze saját teljesítményét (referenciaszemélyek), majd ezután az, hogy az általuk elért, észlelt eredményeket mennyire érzi megérdemeltnek, igazságosnak, végül pedig, hogy milyen szakmai és személyes értékítéleteket fogalmaz meg velük kapcsolatban.

Láthatjuk, hogy a kérdöíves adatfelvétel korlátjaiból adódóan az olyan komplex személyközi jelenségek, mint a negatív kapcsolatok, csak tökéletlen módon vizsgálhatók. Egyetlen kérdés a korábban ismertetett tripartit definíciónak csak egy-egy komponensét képes megragadni, a kutatók pedig több kérdés összekapcsolásával is csak modellszerüen tudnak viszonyulni e kapcsolatokhoz. Mindezt szem előtt tartva talán nem véletlen, hogy a hálózatkutatók közül a negatív kapcsolatokkal foglalkozó szerzők éreznek leginkább indíttatást arra, hogy a pszichológia és a szociálpszichológia társtudományainak eszköztáráért nyúljanak (Casciaro et al., 2015), és kísérletet tegyenek a bevett hálózati paradigma kereteinek feszegetésére, módszertani kiterjesztésére.

\section{Adatelemzési módszerek}

A negatív kapcsolati adatok elemzése komoly kihívások elé állította a pozitív kapcsolatokra kidolgozott módszertani eszközökkel és mérőszámokkal felfegyverkezett hálózatkutatókat. A negatív kapcsolatok azon mechanizmusai, amelyeket az eddigiekben bemutattam, az elérhető elemzési eszköztár egy részét alkalmazhatatlanná teszik. $\mathrm{Az}$ ismert hálózati metrikák jelentős része épített a kapcsolatok magas tranzitivitására (ha A barátja B-nek, és B barátja $\mathrm{C}$-nek, valószínűleg $\mathrm{A}$ is barátja $\mathrm{C}$-nek), ami negatív kapcsolatok esetében nem helytálló; a centralitásmutatók többségének értelmezésekor pedig abból indultunk ki, hogy a kapcsolatokon keresztül valami áramlik a hálózatban (Everett \& Borgatti, 2014). Utóbbit tekintve, a negatív kapcsolatokat vizsgálva azt láthatjuk, hogy bár diadikus szinten a negatív kapcsolatokban is megfigyelhetö áramlás, életszerütlen, hogy több összekapcsolódó negatív kapcsolat azonos áramlást közvetítsen (pl. A nem kedveli B-t, és ezért számára kellemetlen hírt oszt meg vele - $\mathrm{B}$ hiába nem kedveli C-t, valószínütlen, hogy továbbadja az A-tól kapott üzenetet).

Everett és Borgatti (2014) a fenti problémák miatt hiánypótló munkájukban megvizsgálták az ismert hálózati mutatók alkalmazhatóságát, és új mérőszámokat dolgoztak ki. Úgy találták, hogy a pozitív kapcsolatok elemzéséhez használt koncepciók közül egyedül a strukturális ekvivalencia modellje vehető át változtatások nélkül: ez azt mondja ki, hogy A és B szereplő strukturálisan ekvivalensnek számít akkor, ha ugyanazokhoz a szereplőktől indul tőlük, és ugyanazoktól a szereplőktől érkezik hozzájuk negatív kapcsolat. Más koncepciók, mint a fokcentralitás mutatók némi módosítással használhatók, azonban értelmezésükkor eltérő következtetéseket kell levonni. A magas fokcentralitásokból adódó hálózati sürüség pozitív kapcsolatoknál például összetartóbb hálózatra utal. Negatív kapcsolatok esetében viszont a teljes hálózat vonatkozásában ez nem feltétlenül igaz, hiszen a széttagoltabb periféria mellett müködhet összetartó centrum is (Everett \& Borgatti, 2014). Rosszul használhatók azon mutatók, amelyek értelmezésekor az áramlások szerepére kell építenünk (mint a közöttiség-centralitás, vagyis egy szereplő közvetítő funkciójának mértéke).

Továbbra is hasznosnak tünik viszont a szereplők relatív hálózati pozícióját leíró sajátvektor-centralitás (Bonacich-centralitás). Ez azt a szabályszerüséget veszi alapul a pozitív kapcsolatok esetében, hogy egy hálózati szereplö pozíciója erősebb, ha kapcsolataival népszerü (sok kapcsolattal rendelkező, központi) szereplőkhöz kötődik, mintha periférikusabb alterekhez kapcsolódna.

Mivel a negatív kapcsolatok a nagyobb fokú látencia miatt gyakran irányítottak, a sajátvektor-centralitás helyett a $\beta$-centralitás alkalmazása tünik kézenfekvőnek (Bouyssou \& Marchant, 2018), ám ez is csak változtatásokkal lehetséges. Everett és Borgatti (2014) amellett érvelnek, hogy a negatív $\beta$-centralitás úgy értelmezhetö, hogy a népszerü (sok pozitív kapcsolattal rendelkező) szereplőktől érkező negatív kapcsolatok nagyobb gondot okoznak a vizsgált szereplőnek, mint a kevésbé népszerü szereplőktől érkezők. Ennek kifejezésére bevezetik a $h^{*}$ centralitásmutatót, valamint a PN centralitásmutatót, amely pozitív és negatív irányított kapcsolatok egyidejü kezelésére képes. Egy konkrét szervezeti szituációban például a PN mutató lehetővé teszi, hogy összetett módon vizsgáljuk, egy segítségkérő hálózatban hogyan jelenik meg az elkerülés vagy az ellenszenv, és mindez hogyan hat egy-egy szereplő helyzetére vagy a teljes hálózat szerkezetére.

\section{Összefoglalás}

Tanulmányomban a nemzetközi szakirodalom elmúlt évtizedének fontosabb munkái alapján bemutattam a negatív kapcsolatok szervezeti hálózatokban betöltött szerepét és jelentőségét. Ismertettem és összevetettem az általában használatos meghatározásokat, majd négy elemzési szint valamelyikéhez kapcsolva bemutattam a korábbi kutatási eredményekből levonható következtetéseket. Végül röviden rávilágítottam a negatív kapcsolatok kutatásának adatfelvételi és adatelemzési kihívásaira, amelyekre néhány már kidolgozott megoldást kínáltam.

Irodalmi áttekintő tanulmányomban néhány izgalmas kutatási irányra is felhívom a figyelmet. Ilyenek például a negatív kapcsolatok longitudinális vizsgálatából kiinduló dinamikai kérdések, a negatív kapcsolatok mentén kialakuló állandó szerepek, személyes taktikák. Az egyes kapcsolattípusok vizsgálata mind-mind különálló potenciális kutatási irányt jelent, a téma módszertani és tudomány- 
filozófiai hátterének további feltárása ugyancsak kecsegtető lehet. Míg az előbbi révén a jelenlegi hálózatelméleti paradigmán belül tehetünk szert pontosabb adatfelvételi és adatelemzési eszközökre, addig az utóbbi segítségével épp a paradigma határai lehetnek feszegethetők, hogy utat nyissanak a pszichológiai jellegü vagy kvalitatív módszertanra is támaszkodó későbbi kutatások elött.

Tanulmányommal a további akadémiai kutatások inspirálása mellett a hálózatkutatói tanácsadói gyakorlat fejlesztését is támogatni szeretném. A szervezeti hálózatelemzés olyan hatékony diagnosztikai eszköz, amely számos vezetői kihívás megoldására kínál jól értelmezhető információkat, amelyek müködőképes intézkedések és megoldások alapjául szolgálhatnak. Ha beemeljük a negatív kapcsolatokat a vizsgált jelenségek körébe, azzal megszabadulhatunk a kutatások egyik fontos vakfoltjától, és olyan szervezeti kihívásokra adhatunk pontosabb válaszokat, mint a változásvezetés, a tehetséges munkaerő megtartása, vagy a csoportközi konfliktusok kezelése.

\section{Felhasznált irodalom:}

Adams, J., Khan, H. T. A., Raeside, R., \& White, D. (2007). Research Methods for Graduate Business and Social Science Students (1st ed.). Thousand Oaks, CA: Sage Publications.

Bakacsi, Gy. (2004). Szervezeti magatartás és vezetés. Budapest: Aula Kiadó.

Baksa, M., \& Drótos, Gy. (2018). Vállalati közösségi média - A személyközi hálózatok motorja. Vezetéstudomány, 49(4), 2-11.

Boda, Zs., \& Néray, B. (2015). Inter-ethnic friendship and negative ties in secondary school. Social Networks, 43, 57-72. https://doi.org/10.1016/j.socnet.2015.03.004

Borgatti, S. P., Brass, D. J., \& Halgin, D. S. (2014). Social network research: confusions, criticisms, and controversies. In D. J. Brass, G. Labianca, A. Mehra, D. S. Halgin, \& S. P. Borgatti (Eds.), Research in the Sociology of Organizations. Bradford, UK: Emerald Publishing. https://doi. org/10.1108/S0733-558X(2014)0000040001

Borgatti, S. P., \& Foster, P. C. (2003). The Network Paradigm in Organizational Research: A Review and Typology. Journal of Management, 29(6), 991-1013. https://doi. org/10.1016/S0149-2063_03_00087-4

Borgatti, S. P., \& Halgin, D. S. (2011). On Network Theory. Organization Science, 22(5), 1168-1181. https://doi. org/10.1287/orsc.1100.0641

Borgatti, S. P., \& Molina, J. L. (2003). Ethical and Strategic Issues in Organizational Social Network Analysis. The Journal of Applied Behavioral Science, 39(3), 337-349.

Bourdieu, P. (1986). The forms of capital. In J. G. Richardson (Ed.), Handbook of Theory and Research for the Sociology of Education (pp. 241-258). New York, US: Greenwood.

Bouyssou, D., \& Marchant, T. (2018). The $\beta$-ranking and the $\beta$-measure for directed networks: Axiomatic characterizations. Social Networks, 52, 145-153. https://doi. org/10.1016/j.socnet.2017.06.005

Brass, D. J., \& Labianca, G. (1999). Social Capital, Social Liabilities, and Social Resources Management. In R. T.
A. J. Leenders \& S. M. Gabbay (Eds.), Corporate Social Capital and Liability (pp. 323-338). Boston, MA: Springer.

Burt, R. S. (2005). Brokerage and Closure : An Introduction to Social Capital (1st ed.). Oxford, UK: Oxford University Press.

Carver, C. S., \& Scheier, M. F. (2006). Személyiségpszichológia. Budapest: Osiris Kiadó.

Casciaro, T., Barsade, S. G., Edmondson, A. C., Gibson, C. B., Krackhardt, D., \& Labianca, G. (Joe). (2015). The Integration of Psychological and Network Perspectives in Organizational Scholarship. Organization Science, 26(4), 1162-1176. https://doi.org/10.1287/orsc.2015.0988

Coleman, J. S. (1988). Social Capital in the Creation of $\mathrm{Hu}-$ man Capital. American Journal of Sociology, 94, S95S120.

Cross, R. L., Kaše, R., Kilduff, M., \& King, Z. (2013). Bridging the Gap between Research and Practice in Organizational Network Analysis: A Conversation between Rob Cross and Martin Kilduff. Human Resource Management, 52(4), 627-644.

Cross, R. L., \& Parker, A. (2004). The Hidden Power of Social Networks: Understanding How Work Really Gets Done in Organizations. Boston, MA.: Harvard Business Press.

Cross, R. L., \& Thomas, R. J. (2009). Driving Results Through Social Networks: How Top Organizations Leverage Networks for Performance and Growth. San Francisco, CA: Jossey-Bass.

Csaba, Z. L., \& Pál, J. (2010). A negatív kapcsolatok alakulása és hatása: elméleti áttekintés és empirikus tesztelés két középiskolai osztályban. Szociológiai Szemle, 20(3), 4-33.

Ellwardt, L., Labianca, G. (Joe), \& Wittek, R. (2012). Who are the objects of positive and negative gossip at work? A social network perspective on workplace gossip. Social Networks, 34(2), 193-205. https://doi.org/10.1016/j. socnet.2011.11.003

Everett, M. G., \& Borgatti, S. P. (2014). Networks containing negative ties. Social Networks, 38, 111-120.

Fujimoto, K., Snijders, T. A. B., \& Valente, T. W. (2017). Popularity breeds contempt: The evolution of reputational dislike relations and friendships in high school. Social Networks, 48, 100-109. https://doi.org/10.1016/j. socnet.2016.07.006

Galántai, J., Pápay, B., Kubik, B. G., Szabó, M. K., \& Takács, K. (2018). A pletyka a társas rend szolgálatában $\mathrm{Az}$ informális kommunikáció struktúrájának mélyebb megértéséért a computational social science eszközeivel. Magyar Tudomány, 179(7), 964-976. https://doi. org/10.1556/2065.179.2018.7.5

Granovetter, M. (1973). The Strength of Weak Ties. American Journal of Sociology, 78(6), 1360-1380.

Grant, M. J., \& Booth, A. (2009). A typology of reviews: An analysis of 14 review types and associated methodologies. Health Information and Libraries Journal, 26(2), 91-108. https://doi.org/10.1111/j.1471-1842.2009.00848.x

Grosser, T. J., Lopez-Kidwell, V., \& Labianca, G. (2010). A Social Network Analysis of Positive and Negative Gossip in Organizational Life. Group \& Organization Management, 35(2), 177-212. 
Harrigan, N., \& Yap, J. (2017). Avoidance in negative ties: Inhibiting closure, reciprocity, and homophily. Social Networks, 48(1), 126-141.

Hortoványi, L., \& Szabó, Zs. R. (2006). Knowledge and organization: A network perspective. Society and Economy, (2), 165-179. https://doi.org/10.1556 SocEc.28.2006.2.6

Huitsing, G., van Duijn, M. A. J., Snijders, T. A. B., Wang, P., Sainio, M., Salmivalli, C., \& Veenstra, R. (2012). Univariate and multivariate models of positive and negative networks: Liking, disliking, and bully-victim relationships. Social Networks, 34(4), 645-657. https://doi. org/10.1016/j.socnet.2012.08.001

Kane, G. C., Alavi, M., Labianca, G., \& Borgatti, S. P. (2014). What's Different about Social Media Networks? A Framework and Research Agenda. MIS Quarterly, 38(1), 274-304. https://doi.org/10.25300/MISQ/2014/38.1.13

Kiss, K. M. (2005). A kapcsolatháló-elemzés szervezeti lehetőségei. Vezetéstudomány, 36(3), 31-38.

Klein, K. J., Lim, B. C., Saltz, J. L., \& Mayer, D. M. (2004). How do they get there? An examination of the antecedents of centrality in team networks. Academy of Management Journal, 47(6), 952-963. https://doi.org/10.2307/20159634

Kürtösi, Zs. (2007). Az informális kapcsolathálók müködésének nemi különbségei egy szervezetben. Vezetéstudomány, 38(9), 18-29.

Labianca, G. (2014). Negative ties in organizational networks. In D. J. Brass, G. Labianca, A. Mehra, D. S. Halgin, \& S. P. Borgatti (Eds.), Contemporary Perspectives on Organizational Social Networks (pp. 239-259). Bingley, UK: Emerald Publishing.

Labianca, G., \& Brass, D. J. (2006). Exploring the Social Ledger: Negative Relationships and Negative Asymmetry in Social Networks in Organizations. The Academy of Management Review, 31(3), 596-614.

Labianca, G., Brass, D. J., \& Gray, B. (1998). Social Networks and Perceptions of Intergroup Conflict: The Role of Negative Relationships and Third Parties. The Academy of Management Journal, 41(1), 55-67.

Marineau, J. E. (2017). Trust and Distrust Network Accuracy and Career Advancement in an Organization. Group and Organization Management, 42(4), 487-520. https://doi. org $/ 10.1177 / 1059601115627529$

Marineau, J. E., Labianca, G. (Joe), Brass, D. J., Borgatti, S. P., \& Vecchi, P. (2018). Individuals' power and their social network accuracy: A situated cognition perspective. Social Networks, 54, 145-161. https://doi.org/10.1016/j. socnet.2018.01.006

Marineau, J. E., Labianca, G., \& Kane, G. C. (2016). Direct and indirect negative ties and individual performance. Social Networks, 44(1), 238-252.

Mérei, F. (2006). Közösségek rejtett hálózata: Szociometriai értelmezés (4th ed.). Budapest: Osiris.

Obstfeld, D. (2005). Social Networks, the Tertius Iungens Orientation, and Involvement in Innovation. Administrative Science Quarterly, 50(1), 100-130. https://doi. org/10.2189/asqu.2005.50.1.100

Parker, A., Halgin, D. S., \& Borgatti, S. P. (2016). Dynamics of Social Capital: Effects of Performance Feedback on Network Change. Organization Studies, 37(3), 375-397.
Robins, G. (2015). Doing Social Network Research: Network-based Research Design for Social Scientists. Thousand Oaks, CA: SAGE Publications.

Shipilov, A., Labianca, G., Kalnysh, V., \& Kalnysh, Y. (2014). Network-building behavioral tendencies, range, and promotion speed. Social Networks, 39(4), 71-83. https://doi.org/10.1016/j.socnet.2014.03.006

Snow, C. C., \& Fjeldstad, Ø. D. (2015). Network Paradigm: Applications in Organizational Science. International Encyclopedia of the Social \& Behavioral Sciences: Second Edition (Second Edi, Vol. 16). Amsterdam, The Netherlands: Elsevier. https://doi. org/10.1016/B978-0-08-097086-8.73107-2

Sterling, C. M., \& Labianca, G. (Joe). (2015). Costly comparisons: Managing envy in the workplace. Organizational Dynamics, 44(4), 296-305.

Szell, M., Lambiotte, R., \& Thurner, S. (2010). Multirelational Organization of Large-scale Social Networks in an Online World. PNAS, 107(31). https://doi. org/10.1073/pnas.1004008107

Szell, M., \& Thurner, S. (2010). Measuring social dynamics in a massive multiplayer online game. Social Networks, 32(4), 313-329. https://doi.org/10.1016/j. socnet.2010.06.001

Szvetelszky, Zs. (2017). Rejtett szervezetek: Az informális kommunikáció hatalma. Budapest: Typotex.

Tai, K., Narayanan, J., \& McAllister, D. J. (2012). Envy as Pain: Rethinking the Nature of Envy and its Implications for Employees and Organizations. Academy of Management Review, 37(1), 107-129.

Taylor, S. E. (1991). Asymmetrical effects of positive and negative events: The mobilization-minimization hypothesis. Psychological Bulletin, 110(1), 67-85. https://doi.org/http://dx.doi.org/10.1037/00332909.110.1.67

Telegdy, B. (2013). Is the Positive Network the Inverse of Negative Network? International Review of Social Research, 3(3), 21-38.

Tolsma, J., van Deurzen, I., Stark, T. H., \& Veenstra, R. (2013). Who is bullying whom in ethnically diverse primary schools? Exploring links between bullying, ethnicity, and ethnic diversity in Dutch primary schools. Social Networks, 35(1), 51-61. https://doi. org/10.1016/j.socnet.2012.12.002

Török L., G. (2005). Az informális kapcsolati háló és a kompetenciák - Szociometria és 360 fokos értékelés alkalmazása egy felsővezetői team vizsgálata során. Vezetéstudomány, 36(4), 29-44.

Van Wijk, R., Jansen, J. J. P., \& Lyles, M. A. (2008). Inter and Intra Organizational Knowledge Transfer: A Meta Analytic Review and Assessment of its Antecedents and Consequences. Journal of Management Studies, 45(4), 830-853. https://doi.org/10.1111/j.14676486.2008.00771.x

Venkataramani, V., Labianca, G. (Joe), \& Grosser, T. (2013). Positive and Negative Workplace Relationships, Social Satisfaction, and Organizational Attachment. Journal of Applied Psychology, 98(6), 10281039. 